Nineteenth-

Century

Music Review

\title{
Volume 3 Issue 1
}




\section{Nineteenth-Century Music Review}

\section{VOLUME 3, ISSUE 1 \\ 2006}

\section{ASHGATE}

Published in association with the Centre for Nineteenth-Century Music, Durham University, UK 
Letters to the Editor For any communication concerning published articles or reviews, please send letters by email or hard copy to the General Editor:

Dr Bennett Zon

School of Music

Durham University

Palace Green

Durham DH1 3RL

England

Email: bennett.zon@durham.ac.uk

Subscriptions For the latest information about the price of the journal and details of how to subscribe, please contact:

Nicky Staszkiewicz

Ashgate Publishing Limited

Gower House

Croft Road

Aldershot

Hants GU11 3HR

England

Tel: +44 (0)1252 351804

Fax: +44 (0)1252 351839

Email: journals@ashgatepublishing.com

\section{Themed Issues}

The General Editor of Nineteenth-Century Music Review encourages proposals from individuals with ideas for themed issues, involving the commissioning of up to six main articles per issue, as well as one or more review articles for coverage of books, CDs and scores. Those applying to the journal for this purpose should initially provide the General Editor with a statement of no more than 500 words, outlining the thematic nature of the proposed issue, the names of contributing authors along with a working title for their papers, and a timetable for submission of work.

Proposers of themed issues work alongside the General Editor, and are designated Guest Editors. They are responsible for commissioning, organizing and preparing articles for publication, as well as working closely with review editors to locate suitable material and authors for relevant sections of the journal. Review sections of themed issues are not exclusively thematicized, and tend towards a balance of half themed, and half general material.

Articles commissioned for themed issues follow the same process of peerreview as general issues. No guarantee of publication can be given to specially commissioned authors. 


\title{
Nineteenth-Century Music Review
}

\author{
Editor of this Issue \\ James Deaville \\ General Editor of this Issue \\ Bill Weber
}

\author{
Book Reviews Editor \\ Anna Celenza \\ CD Reviews Editor \\ Jeremy Dibble \\ Score Reviews Editor \\ Stephen Downes
}

\section{Editorial Board}

Dr Bennett Zon, Durham University, UK (General Editor)

Professor Anna Celenza, Peabody Conservatory and Johns Hopkins University, USA (Book Reviews Editor)

Professor Jeremy Dibble, Durham University (CD Reviews Editor)
Dr Stephen Downes, University of Surrey, UK (Score Reviews Editor)

Professor William Weber, California State University, Long Beach, USA

Dr Phyllis Weliver, Wilkes University, USA

\section{Advisory Board}

Dr Rosamund Bartlett, Durham University, UK

Professor Andrew Bowie, Royal Holloway, University of London, UK

Dr Geoffrey Chew, Royal Holloway, University of London, UK

Professor John Deathridge, King's College, University of London, UK

Professor Annegret Fauser, University of North Carolina, Chapel Hill, USA

Dr Peter Franklin, University of Oxford, UK

Dr Sophie Fuller

Professor Lydia Goehr, Columbia University, USA
Professor Thomas Grey, Stanford University, USA

Professor Hervé Lacombe, Université Rennes 2 - Haute Bretagne, France Professor Roberta Marvin, University of Iowa, USA

Professor Simon McVeigh, Goldsmiths College, University of London, UK

Professor Julian Rushton, University of Leeds, UK

Professor Jim Samson, Royal Holloway, University of London, UK Professor Manuela Schwartz, Hochschule Magdeburg/Stendal (FH), Germany Professor Nicholas Temperley, University of Illinois, USA 
All rights reserved. No part of this publication may be reproduced, stored in a retrieval system, or transmitted in any form or by any means, electronic, mechanical, photocopying, recording or otherwise, without the prior permission of the publisher.

Published by

Ashgate Publishing Limited

Gower House

Croft Road

Ashgate Publishing Company

Aldershot

Hants GU11 3HR

Suite 420

101 Cherry Street

England

This journal is the successor of the Music Review, founded by the late Geoffrey Sharp, which then continued for many years under the ownership of the late A.F. Leighton-Thomas.

Ashgate website: http://www.ashgate.com

ISSN: 1479-4098

Typeset by Manton Typesetters, Louth, Lincolnshire

Printed by MPG Books Ltd, Bodmin, Cornwall 


\section{Contents}

\section{Volume 3, IsSue 1}

James Deaville

Introduction: Music and Cultures of Racial Representation in the ix Nineteenth Century

\section{Articles}

Derek B. Scott

In Search of Genetically Modified Music: Race and Musical Style in the Nineteenth Century

Bennett Zon

Disorienting Race: Humanizing the Musical Savage and the Rise of

British Ethnomusicology

Ralph P. Locke

Aida and Nine Readings of Empire

Michael V. Pisani

John Philip Sousa's 'Red Indians': A Case Study of Race in Music

James Deaville

African-American Entertainers in Jahrhundertwende Vienna: Austrian Identity, Viennese Modernism and Black Success

\section{REVIEWS}

\section{Review Article}

James R. Currie

Adorno - and Now the Act

Book Reviews

Clair Rowden

The Cambridge Companion to Grand Opera edited by David Charlton

William Weber

The Ideal World of Mrs. Widder's Soirée Musicale: Social Identity and

Musical Life in Nineteenth-Century Ontario by Kristina Marie Guiguet

Steven Vande Moortele

Bruckner's Symphonies. Analysis, Reception and Cultural Politics by

Julian Horton

Gurminder Bhogal

Mallarmé and Debussy: Unheard Music, Unseen Text by Elizabeth

McCombie 
Books Received

CD Reviews

Walter Aaron Clark

Albéniz: Sonatas for Piano; L'Automne (Valse); Sonata No. 3; Sonata

No. 4; Sonata No. 5. Albert Guinovart pf. Granados: Goyescas; Los

Majos Enamorados; El Pelele; Intermezzo (version for piano by A.

Guinovart). Albert Guinovart $p f$

Paul Hale

Best: The Organ Music of W.T. Best. Christopher Nickol org

Jeremy Barham

Mahler: Lieder und Gesänge (selection); Lieder eines fahrenden

Gesellen; Fünf Rückert-Lieder; Kindertotenlieder. Stephan Genz bar; Roger Vignoles $p f$

Scott Warfield

Richard Strauss: Symphony No. 2 in F minor op. 12; Romanze in

F major; Six Songs op. 68. Eileen Hulse sop; Raphael Wallfisch vc;

Royal Scottish National Orchestra; Neeme Järvi cond

David Fanning

Tchaikovsky: Eugen Onegin, Opera in Three Acts. Gertrude Jahn

(Larina); Mirella Freni (Tatyana); Rohangiz Yachmi (Olga);

Margaritha Lilowa (Filipjevna); Wolfgang Brendel (Eugen Onegin);

Peter Dvorsky (Vladimir Lenski); Nicolai Ghiaurov (Fürst Gremin);

Choir and Orchestra of the Vienna State Opera; Seiji Ozawa cond

CDs Received

Score Reviews

William Drabkin

Beethoven: Piano Sonata in G major op. 31 no. 1; Piano Sonata in

D minor op. 31 no. 2 ('Tempest'); Piano Sonata in Eb major op. 31 no. 3, edited by Norbert Gertsch and Murray Perahia, fingering by Murray Perahia

Derek Katz

Dvořák: Piano Concerto in G minor op. 33. Facsimile, with a preface by András Schiff and introductions by Jarmila Tauerová and Jan Dehner

Laura Tunbridge

Schumann: Abegg Variationen op. 1; Fantasiestücke op. 12; Kreisleriana op. 16; Faschingsswank aus Wien op. 26; Urtext editions, edited by Ernst Herttrich

Daniel Grimley

Sibelius: Symphony no. 2 in D major op. 43. Study Score edited by Kari Kilpeläinen 
Scores Received

Guidelines for Contributors 